\title{
Sul linguaggio grafico di sintesi: segni e simboli nel mondo reale e virtuale
}

\author{
Gabriella Curti
}

\section{Abstract}

Un complesso sistema di simboli è ormai patrimonio di uso comune. In questo sistema le immagini prodotte sono espressione di un linguaggio di sintesi e contengono numerosi elementi paradigmatici. La grafica dei segni può essere tradizionale o innovativa e molte deroghe alle regole - fissate soprattutto in riferimento a quelli più utilizzati nei luoghi di transito e negli spazi di uso comune - rendono ancora più interessante il settore della produzione laddove l'aspetto creativo è altamente sviluppato. Si considerano i simboli come unici mezzi di espressione in sostituzione delle parole e dei messaggi di testo e unici modi universali di comunicazione per rendere possibile la comprensione.

Tuttavia, se inizialmente al simbolo si è fatto ricorso essenzialmente per superare le barriere linguistiche, oggi al simbolo si ricorre per comunicare qualunque tipo di informazione e non solo quelle utili. Nei dispositivi tecnologici di uso quotidiano si leggono numerosi simboli per la comunicazione che utilizzano un repertorio di segni pressoché identici ma con molte sottili differenze.

Nell'attuale riflessione si considerano pertanto sia le regole grammaticali e sintattiche per l'uso degli elementi dell'alfabeto del linguaggio visivo sia le numerose variabili utilizzate che connotano in maniera visibilmente marcata alcune recenti realizzazioni.

\section{Parole chiave}

comunicazione visiva, graphic design, segno, simbolo, pittogramma.
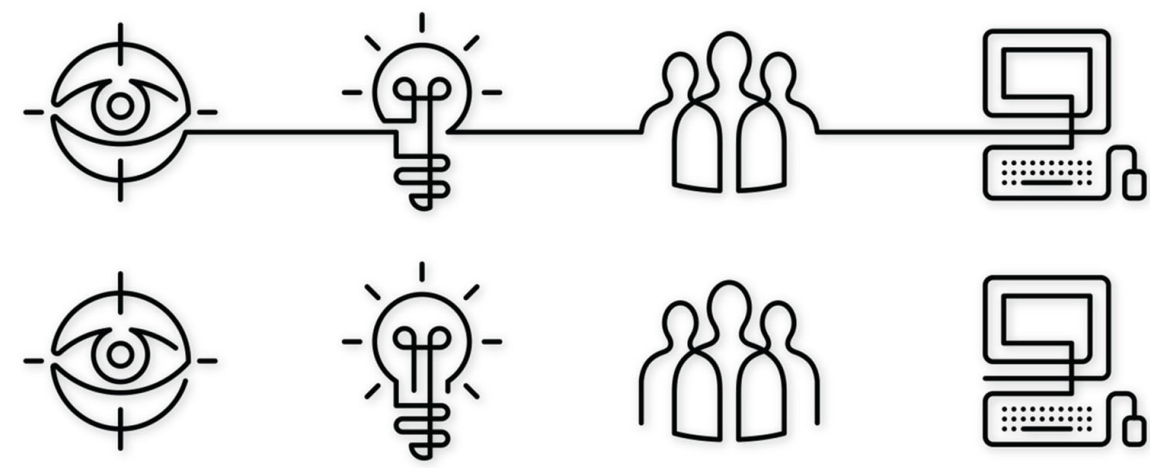


\section{Introduzione}

Nel definire il segno C. S. Peirce ne ha evidenziato l'importanza in quanto simulacro dell'oggetto a cui si riferisce, e numerosi studi conseguenti hanno documentato finanche la circolazione dei segni nella vita sociale in quantità pressoché illimitata [I]. II segno, in quanto immagine, appartiene a un sistema di comunicazione e può produrre numerosi esiti anche diversi. "Pittogramma è un segno iconico il cui referente è un oggetto o una particolare classe di oggetti o ancora la particolare qualità o azione che la classe di oggetti può designare" [2]. I pittogrammi in quanto simboli sono ormai universalmente noti e considerati come gli efficaci mezzi di espressione in sostituzione delle parole e dei messaggi di testo e gli unici modi universali di comunicazione per rendere possibile la comprensione in ogni luogo. Può sembrare superfluo ricordare che inizialmente si è fatto ricorso al simbolo essenzialmente per superare le barriere linguistiche, mentre si intende sottolineare che oggi si ricorre al simbolo per comunicare qualunque tipo di informazione e non solo quelle utili [3].

I simboli sono anche strumenti per la comunicazione di concetti astratti, di idee e dunque un linguaggio di astrazione deve essere adottato per realizzarli. Pertanto, si può fare riferimento al sistema codificato di segni e simboli come repertorio dal quale trarre concetti che superano non solo le barriere linguistiche, ma anche e soprattutto le barriere culturali. A questo proposito si ricorda un famoso esempio, il più importante tra i simboli realizzati per le attività sportive, un simbolo che si riferisce alle Olimpiadi, cioè alla manifestazione organizzata per far rivivere i giochi Olimpici dell'antica Grecia. Presentato sopra il tessuto di una bandiera bianca, il simbolo delle Olimpiadi era costituito da cinque cerchi intrecciati, rappresentativi dei cinque continenti presenti ai Giochi Internazionali. Nel I 894 era già stata fondata un'organizzazione non governativa denominata Comitato Internazionale Olimpico $(\mathrm{ClO})$. II fondatore Pierre de Coubertin (che presentò la bandiera in forma ufficiale successivamente) aveva stabilito nella forma circolare la rappresentazione del territorio continentale. L'intreccio delle forme significava la compresenza dei cinque continenti alla manifestazione. Nel 1913 egli espose la sua idea nella Rivista Olimpica e questa idea costituì il preambolo della Carta Olimpica in cui venne ribadito il concetto di unione che si sarebbe realizzato mediante l'incontro ai Giochi Olimpici degli atleti di tutto il mondo. Successivamente alla sua presentazione, la bandiera olimpica fu utilizzata al Congresso Olimpico di Parigi dell9|4.

In questo caso, il cerchio non è soltanto un elemento dell'alfabeto delle forme di riferimento per la realizzazione dei simboli (più frequentemente abbinato ai simboli di divieto) ma una forma che esprime il concetto di territorio in tutta la sua ampiezza e addirittura di un intero continente. Inoltre, l'unione dei cerchi può essere simbolica di fratellanza, come nel caso specifico che ha determinato una logica conseguenza. Infatti, si ritrova un esempio analogo tra i simboli realizzati per Agenda 2030 [4] dalle Nazioni Unite. L'ONU indica di adoperare l'intero logo costituito da una ruota gigante assieme ai diciassette simboli separati.Tra questi il simbolo n. 17 - Partnership per gli Obiettivi - presenta l'unione di cinque cerchi intrecciati che esprime l'esigenza del partenariato come obiettivo conclusivo, probabilmente per raggiungere tutti gli altri. Raffrontando dunque i due simboli si scopre una evidente analogia (fig. I).

A tale proposito, si ricordano alcune considerazioni di Rudolf Arnheim: "Un semplice cir-

Fig. I. L'impiego del cerchio in due simboli e olimpici sovrapposti logo dei giochi olimpici logo del giochi olimpici (Messico/1968) affiancato a Sviluppo Sostivi per (ONU/Agenda 2030).

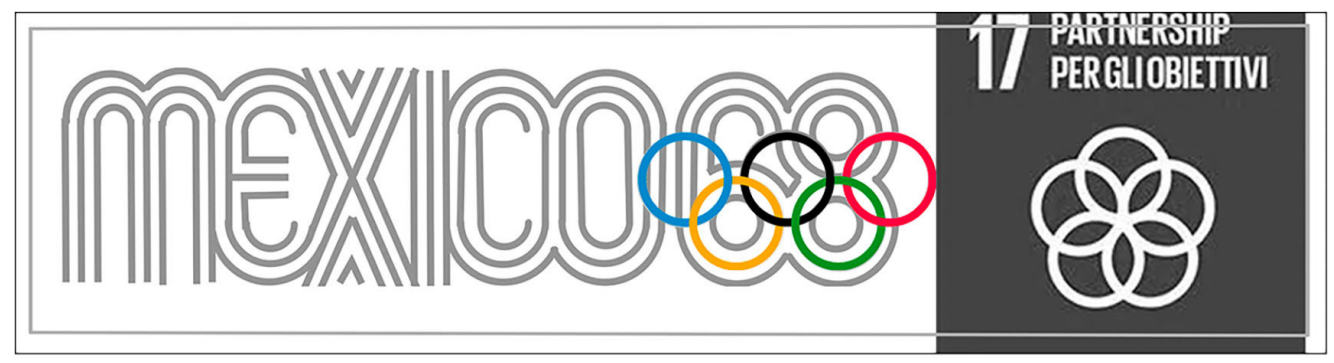


colo o un punto può bastare a rappresentare una città, una figura umana, un pianeta; può servire alla funzione data assai meglio di un ritratto più particolareggiato [...] Sfere, dischi, anelli, che sono la forma più indifferenziata e universale, occupano un posto preminente nei più primitivi modelli della configurazione della terra e dell'universo, non tanto sulla base di osservazioni ma perché si tende a rappresentare le forme e i rapporti spaziali sconosciuti nel modo più semplice" [5].

Punto - linea - superficie per la costruzione del simbolo
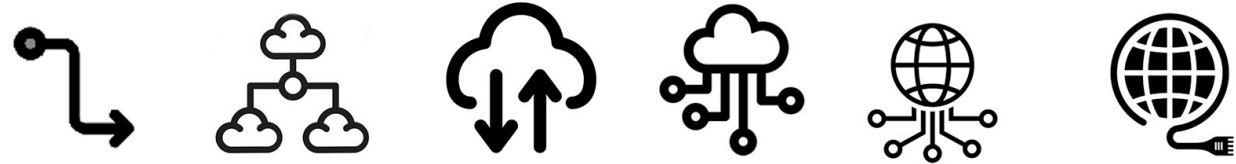

In generale, dall'osservazione del vasto repertorio di simboli esistenti possono essere desunte alcune formulazioni ripetitive per una sintesi opportuna di riferimento che possa appunto servire per una individuazione delle regole di base. Queste regole grammaticali e sintattiche determinano la composizione degli elementi dell'alfabeto del linguaggio visivo - punto-linea-superficie. Qualche sottile differenza nell'uso degli elementi accresce notevolmente il valore della efficacia nella comunicazione e trasmissione di alcuni concetti, e l'osservazione di queste differenze può suggerire la codificazione di altre nuove regole.

Utilizzando alcune variabili, la diversa combinazione dei tre elementi base produce molti altri risultati. Le dimensioni del punto possono variare e anche le proprietà delle linee che possono essere intere o tratteggiate, lineari o curvilinee, di spessore minore o maggiore (fig. 2). Inoltre, numerose possono essere le differenze nelle superfici utilizzate, e ognuna di queste differenze può essere determinante. Osservando le superfici, è possibile considerare la configurazione propria delle forme: cerchio-quadrato-triangolo. Queste semplici forme di riferimento hanno un significato preciso anche in base alle regole codificate dall'International System of Typographic Picture Education (Isotype) [6] organismo che regolamenta la progettazione dei simboli per garantirne la comprensibilità e aumentarne l'efficacia con un rigido apparato di regole che ogni progettista grafico deve attentamente seguire e applicare.

\section{Le forme in relazione al significato dei simboli}

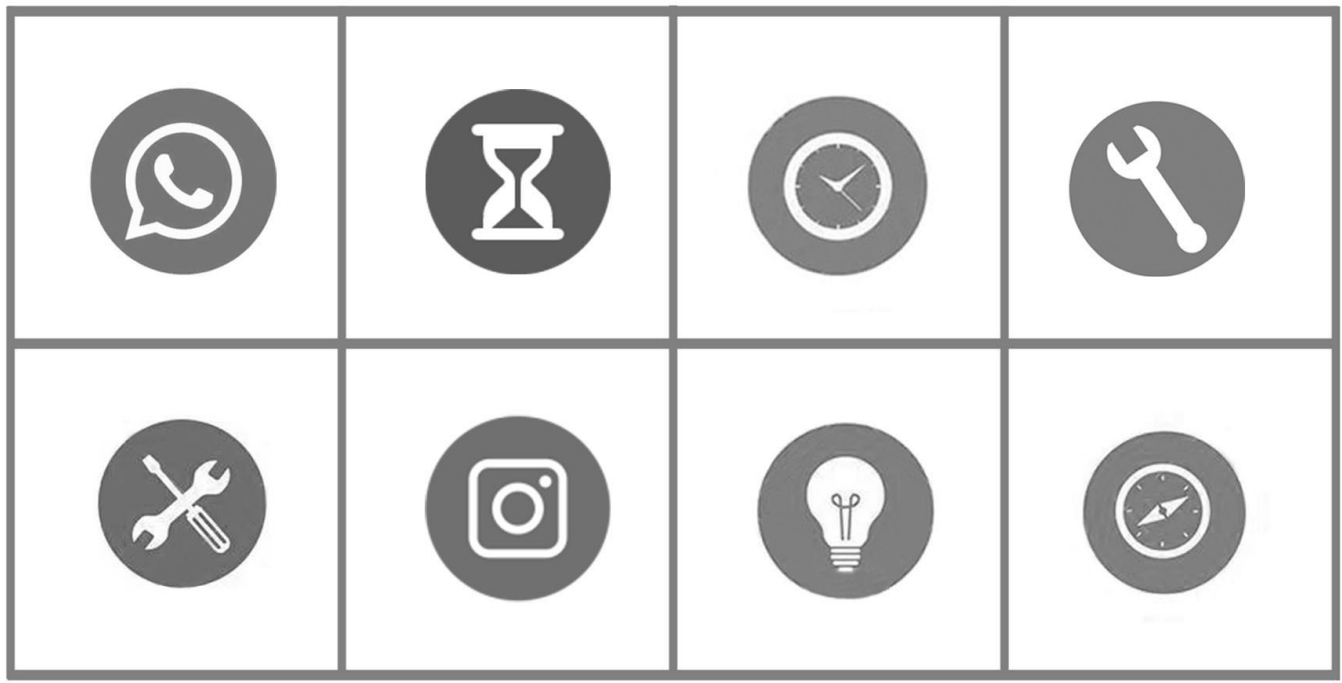


Per quanto riguarda la forma del simbolo, si può considerare la sua maggiore o minore efficacia anche in relazione al suo uso nei luoghi, affinché abbia una sistemazione adeguata. Ogni rappresentazione simbolica può così essere convalidata nella sua forza espressiva e comunicativa. La forma del cerchio - nota prevalentemente nella segnaletica stradale - è largamente impiegata nella gran parte dei simboli, come quelli che si riferiscono agli strumenti, da quelli semplici a quelli complessi.

Alla vasta produzione dei simboli presenti nei luoghi fisici, dagli spazi urbani aperti alle aree stradali, compreso i luoghi di transito (aeroporti-porti-stazioni ferroviarie ecc.), si deve aggiungere la produzione dei simboli utilizzati per i luoghi virtuali, di recente introduzione ma già largamente presenti in tutti i dispositivi di uso quotidiano.

La comunicazione che si attua nei luoghi virtuali dell'universo digitale già si avvale di una rappresentazione simbolica ampia che appare sugli schermi digitali assieme alle parole (si ricordano le emoji, per fare un esempio) ma analogamente tutti i vari dispositivi utilizzati presentano altri simboli che dovrebbero facilitare il ricorso a questi strumenti e alle loro nascoste potenzialità.

In sintesi quindi, se da una parte si nota che la simbolica rappresentazione di tutto ciò che è collegato agli aspetti tecnici sta nell'impiego di elementi/oggetti che appartengono al repertorio tradizionale e sono facilmente riconoscibili come la bussola, l'orologio, la lampadina, la chiave inglese, la busta per lettere, la cornetta del telefono, tanto per citarne alcuni (fig. 3), dall'altra, si osserva che la simbolica rappresentazione di tutto ciò che è collegato agli aspetti visuali, mentali o speculativi, è riferita ai luoghi concettuali, agli spazi per la mente. I simboli che rappresentano la cosiddetta realtà virtuale (fig. 4) sono la contemporanea testimonian-

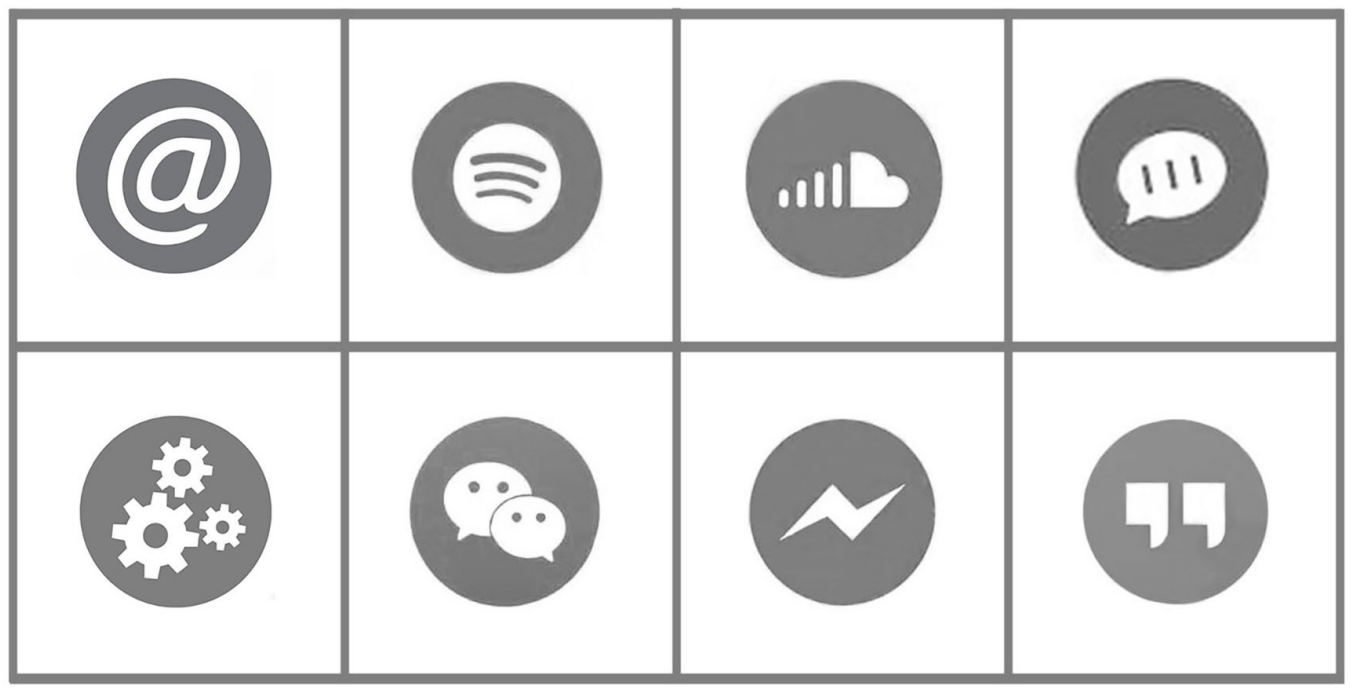

za dell'allargamento degli strumenti utilizzabili per la comunicazione e non usano riferimenti a strumenti concretamente esistenti ma a qualcosa che sta tra la metafora e il paradigma. La forma circolare o quadrata indifferentemente impiegata per contenere tali simboli è strettamente connessa al supporto sul quale dovranno essere posizionati, allo spazio nel quale dovranno essere contenuti che varia tra un touch screen di uno smartphone oppure di un iPhone, di un tablet oppure di un iPad, pertanto è strettamente funzionale alla progettazione dello strumento tecnologico.

Inoltre, nell'universo digitale gli spostamenti possono essere guidati allo stesso modo che nel mondo reale, pertanto esiste un'ampia produzione di simboli che trasmettono le numerose possibilità di connessione tra gli utenti delle piattaforme virtuali, questa volta rielaborando con sottili differenze i singoli elementi paradigmatici (fig. 5). 


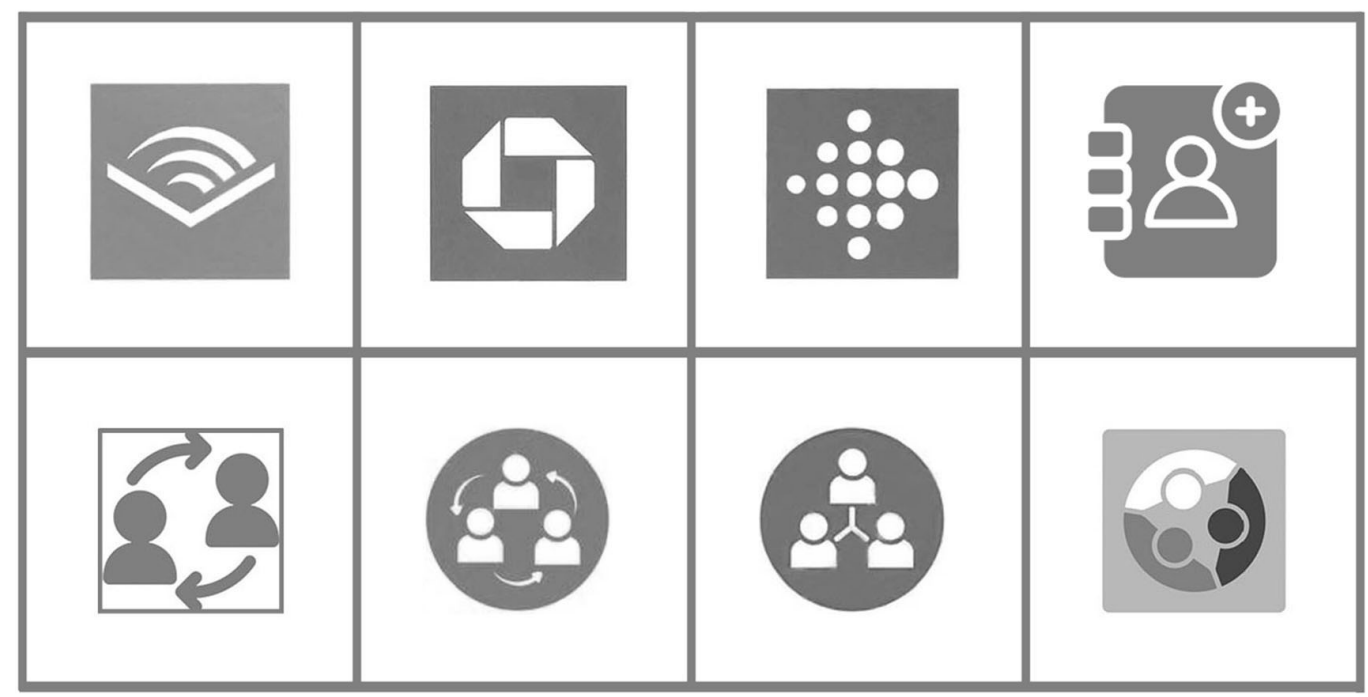

Le piattaforme virtuali sono le aree comuni, gli spazi aperti condivisibili come le aule scolastiche e universitarie, le sale per i forum, le sedi per discutere e confrontarsi. Inoltre, le piattaforme digitali per gli acquisti rendono possibile visionare la merce in vendita, come accade nelle grandi piazze di mercato. Per quest'ultima possibilità di utilizzare le piattaforme in Internet, proprio come se si andasse a visitare il mercato, i simboli comunicano le modalità di condivisione, di utilizzazione degli spazi per le compravendite e ogni altro genere di transazione. Laddove sono stati inseriti dei riferimenti agli individui, mediante schemi che uniscono la rappresentazione del volto a quella del busto, molte ulteriori esemplificazioni utilizzano punti-linee-superfici nelle numerose variabili e soprattutto il colore (fig. 6).

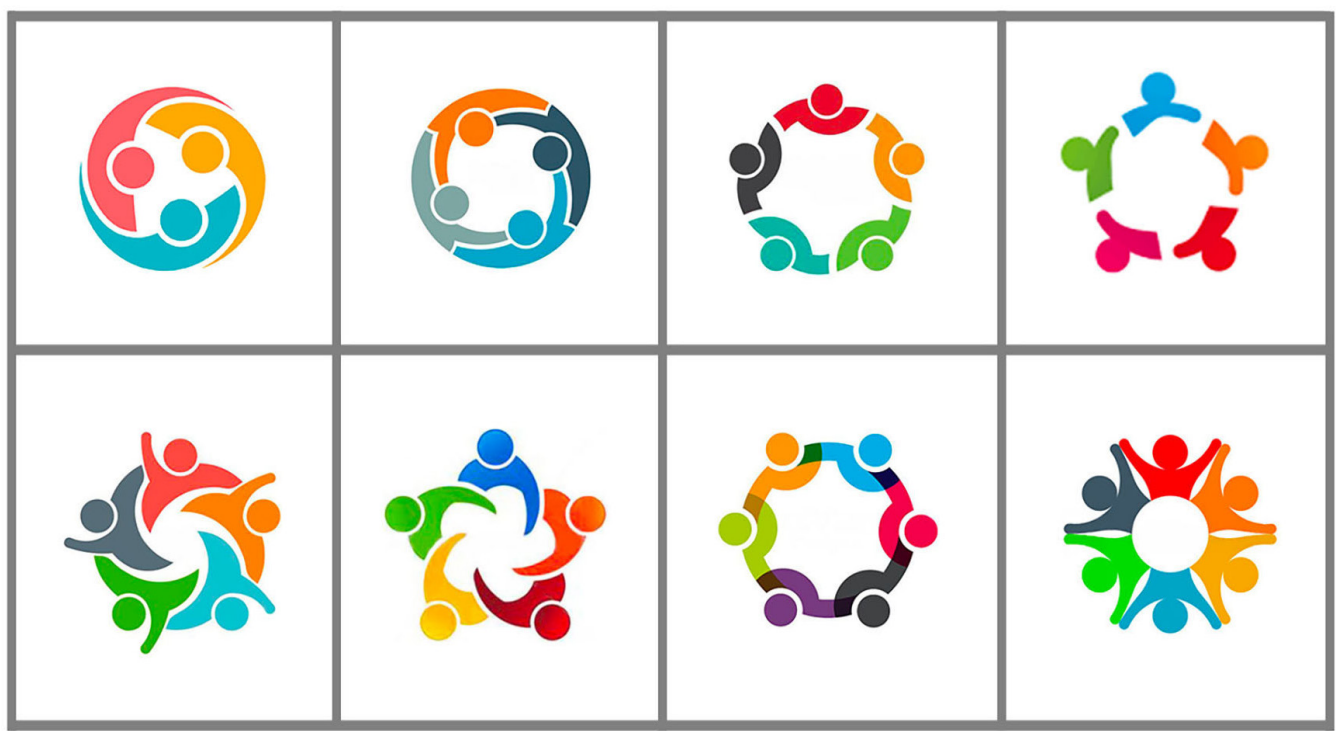

Infine, una riflessione può essere aggiunta alle precedenti, facendo riferimento alle altre possibilità di configurazione grafica insite nelle differenziazioni tra gli elementi tracciati e quelli incisi o scavati, prendendo in considerazione i numerosi simboli che mostrano questo effetto grafico. Pertanto, anche guardando un solo elemento cioè la linea, un'osservazione sulla differenza tra la linea come traccia e la linea come solco può essere fatta considerando i due simboli della TVWi-Fi (fig. 7). 
Fig. 7. Punti - Linee delle Connessioni Wi-Fi.

Fig. 8. Studio del tracciato geometrico per il simbolo delle Connessioni Wireless.
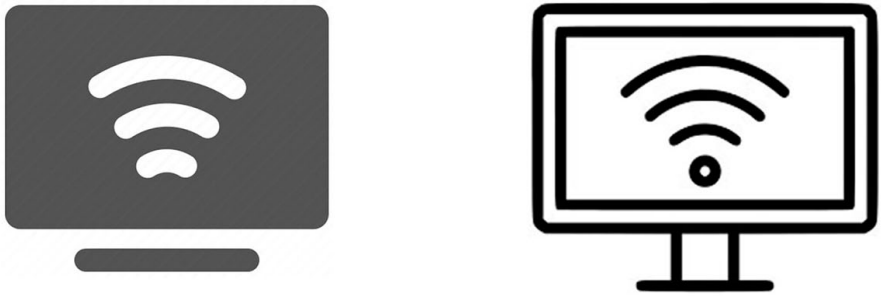

Per il simbolo del Wi-Fi (Wireless networking Technology) si possono considerare numerose varianti anche se si tratta di un esempio estremamente semplice. La forma del triangolo rovesciato emerge dalla sequenza dei solchi paralleli, che possono essere sostituiti dai segni paralleli piuttosto marcati con alcune varianti anche nei raggi di curvatura degli archi, simbolica rappresentazione della propagazione delle onde sonore (fig. 8).

Tuttavia, come sottolineato in precedenza, a proposito della specificità delle forme per questa categoria di simboli non si rileva una scelta precisa se non in relazione agli spazi virtuali o ai dispositivi di inserimento.

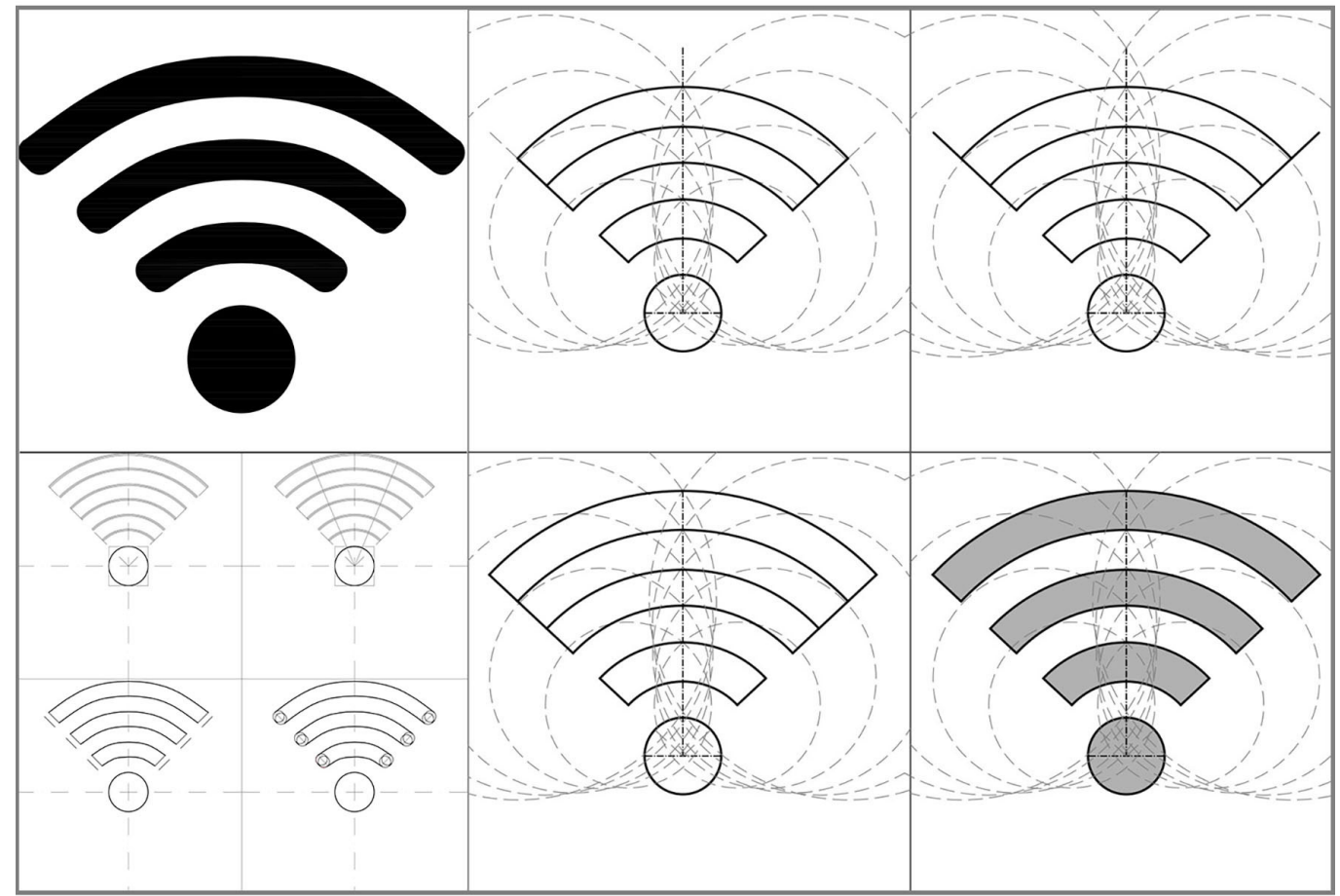

\section{Geometrie di riferimento}

Dalla lettura di numerosi esempi, dunque, è emerso che per la costruzione del simbolo si ricorre utilmente alle impostazioni essenziali come assialità e simmetria, modularità e ripetizioni, e alle operazioni geometriche necessarie: ribaltamenti, rotazioni e traslazioni, considerando una equa distribuzione degli elementi di base. Pertanto, si può tranquillamente affermare che le composizioni tra punti-linee-superfici appaiono regolate da strutture geometriche regolari [7]. 
Fig. 9. Studio geometrico per la costruzione di un simbolo sulle Connessioni tra persone.
Fig. I O. Studio del

tracciato geometrico per il Nastro di Moebius, il simbolo frequentemente utilizzato per indicare la possibilità di iciclo del prodotto.
La composizione degli elementi si avvale nel complesso della rigida geometria della griglia; questa appare come principale strumento, una sorta di guida nascosta, molto ben dissimulata ma latente in ogni simbolica rappresentazione.

Per ogni costruzione dei più noti e diffusi simboli di riferimento è possibile individuare la costruzione geometrica che ne regola forme e dimensioni (fig. 9), mantenendo proporzioni ben controllate per un equilibrio globale. La costruzione geometrica inoltre può awalersi in taluni casi delle proporzioni numeriche crescenti o decrescenti in base alle note sequenze numeriche.

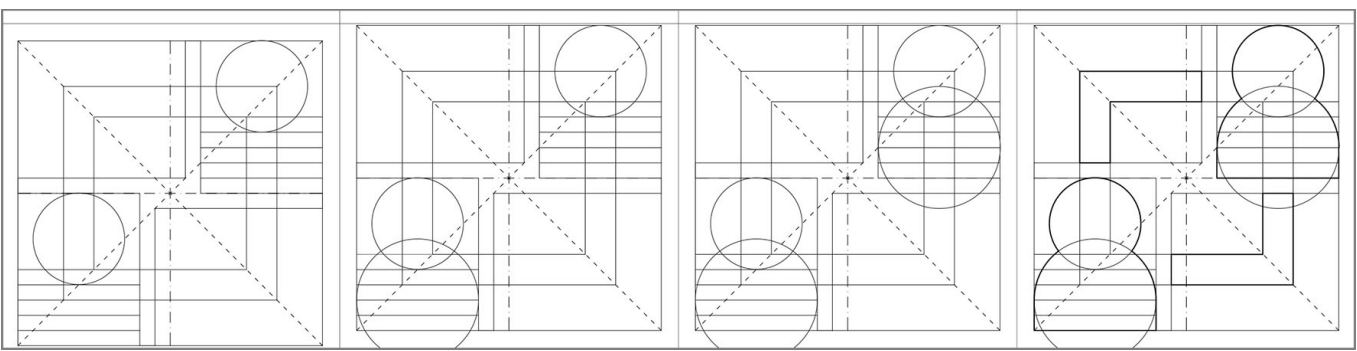

In tal modo sono garantiti i migliori risultati anche in riferimento alla efficacia della trasmissibilità e della comprensione.

Per concludere, si è inteso proporre una lettura analitica dell'impianto geometrico di riferimento di alcuni simboli che richiedono una certa attenzione da parte degli utenti. Si tratta di esempi presenti pressoché ovunque, laddove occorre avvertire del contenuto di alcune confezioni, per il loro smaltimento oppure per la pericolosità delle sostanze. In tal caso la forma privilegiata in uso è il triangolo, molto diffuso per ogni riferimento al pericolo e al rischio, basti pensare ai segnali stradali di pericolo generico o di dissesto. II triangolo è inoltre il più comune riferimento a un dispositivo da usare in caso di emergenza.

La geometria regolare del triangolo equilatero, le partizioni interne e le divisioni degli angoli rendono più agevole l'introduzione di elementi simmetrici e l'uso di rotazioni e ribaltamenti come è possibile notare sia nel tracciato geometrico di riferimento del simbolo per la riciclabilità di alcuni materiali, sia in quello per l'indicazione della tossicità o pericolosità di alcune sostanze in uso nei laboratori chimici o negli ospedali. Quest'ultimo simbolo peraltro è riprodotto a colori e nell'abbinamento prevalente dei colori giallo-nero di estrema efficacia per attrarre l'attenzione (figg. I0, II).

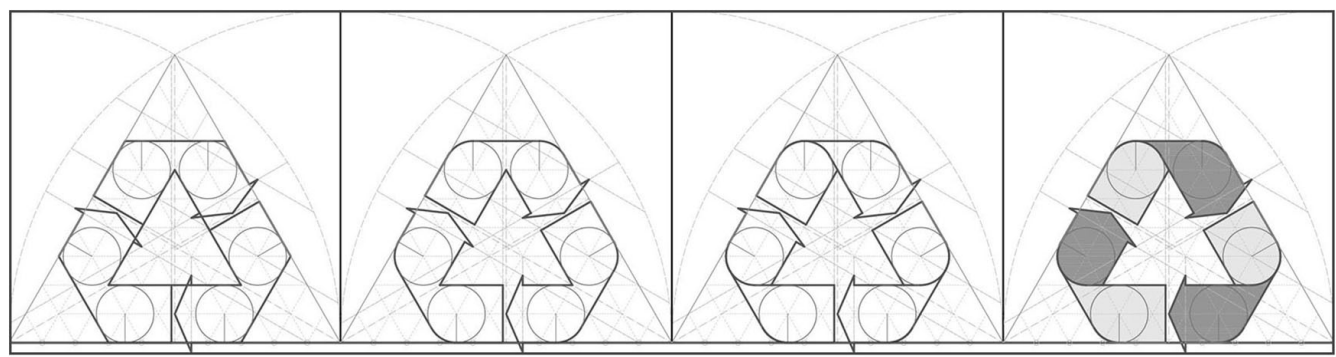

Rispetto a questi ultimi esempi, diffusi nel mondo reale e non in quello virtuale, l'associazione tra forma e significato appare più complessa, ma altro non è che la trascrizione in una immagine di un pensiero, un'idea che può essere tradotta in un suggerimento, un consiglio. Il concetto astratto trova ancora più difficilmente la traduzione in una immagine plausibile e può dare adito a numerosi fraintendimenti, pertanto i molti simboli già esistenti e i nuovi che saranno introdotti, oltre al vasto repertorio di simboli riferiti all'universo digitale e allo spazio virtuale, probabilmente potranno rivelarsi attendibili e comprensibili soltanto nel tempo. 
Fig. I I. Studio del simbolo usato per indicare la pericolosità, degli ambienti o dei prodotti, applicabile ovunque.

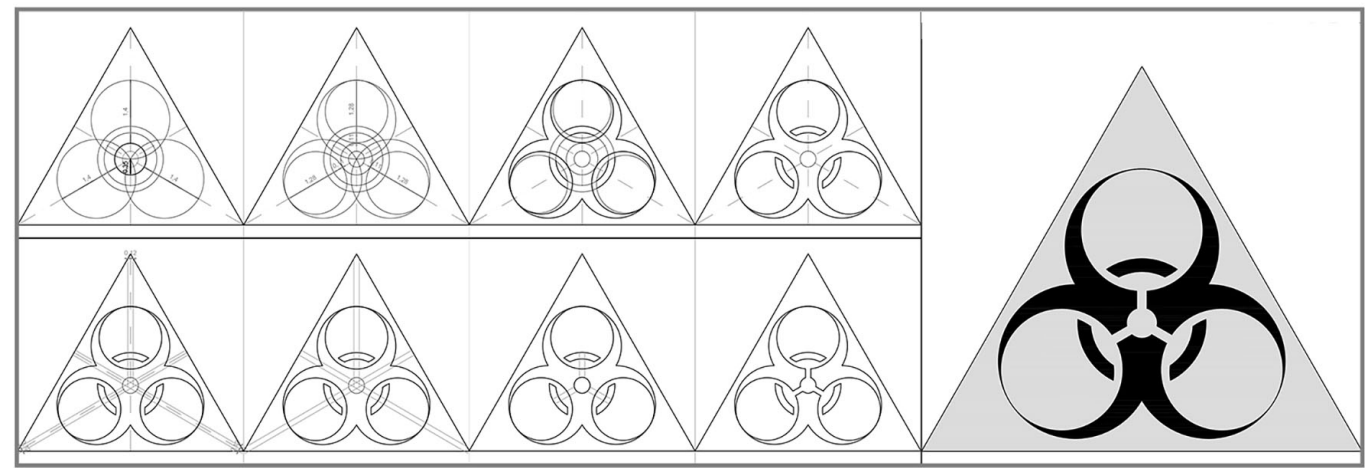

\section{Note}

[ I] Nella sua teoria sulla Semiotica, Charles Sanders Peirce individuò tre elementi indispensabili: segno-oggetto-interpretante. suoi saggi risalgono al periodo 1867 - 1893 e vennero tradotti in Italia a partire dal 1956. A tale proposito si veda la bibliografia ragionata in <http://www.peirce.unimi.it> (consultato il 27 febbraio 202 I).

[2] Sergio Polano, II ritorno dei pittogrammi. La semiosi si camuffa, in Polano, Vetta 2002, pp. 39, 40.

[3] A tale proposito, Rudolf Arnheim scrisse: "L'uso della parola 'simbolo' è oggi talmente frequente che può venire impiegata indiscriminatamente ogni qualvolta una cosa prende il posto di un'altra." Arnheim 1974, Cap. IV Sviluppo, p. I44.

[4] Le icone sono in tutto 17 e si aggiungono alla ruota colorata, cioè al logo del Sustainable Developement Goals (SDG) per promuovere graficamente la sensibilizzazione degli Obiettivi di sviluppo sostenibile adottati dagli Stati Membri delle Nazioni Unite dalla risoluzione A/RES/70/I dell'Assemblea Generale del 25 settembre 20I5. Fonte: unric.org SDG-linee-guida (consultato il 22 febbraio 2021 ).

[5] Arnheim 1974, I Balance, p. 147 e p. 154.

[6] Isotype, sistema basato sui pittogrammi, viene definito "linguaggio internazionale per immagini" e anche "linguaggio visivo ausiliario", grazie al quale i segni usati devono essere caratterizzati da semplicità, riconoscibilità, immediatezza, seppure venga utilizzata una ridotta palette dei colori che presenta soltanto i colori base: giallo-rosso-blu-verde abbinati al bianco e al nero.

[7] Si veda la sintesi sulle strutture geometriche del cerchio-quadrato-triangolo in Spera 200 I, Le basi della grafica, pp. 94-98.

\section{Riferimenti bibliografici}

Arnheim R. (2020). Arte e percezione visiva. Milano: Feltrinelli [Prima ed. Art and Visual Perception. A Psychology of the Creative Eye. Los Angeles, 1974].

Aymerich M. (2008). Simboli, pittogrammi \& silhouette. Modena: Logos. [Prima ed. Symbols, pictograms \& silhouettes. Barcelona 2008].

Fioravanti G. (2002). II nuovo manuale del grafico. Bologna: Zanichelli.

Frutiger A. (1989). Signs and Symbols: their design and meaning. New York:Van Nostrand Reinhold.

Gallagher M., Savard L. (2006). 1000 simboli e pittogrammi: comunicazione visiva per tutte le lingue. Modena: Logos.[Prima ed. 1000 lcons, Symbols + Pictograms. Beverly MA, 2006].

Leveni P. (20 I3). In forma di parola: pittogrammi, ideogrammi, alfabeti, scritture dalla preistoria all'età moderna. Milano: BookTime. Polano S., Vetta P. (2002). Abecedario la grafica del novecento. Milano: Mondadori Electa.

Spera M. (200 I). La progettazione grafica tra creatività e scienza. Roma: Gangemi editore.

Autore

Gabriella Curti, Università degli Studi Mediterranea di Reggio Calabria, gabriella.curti@unirc.it

Per citare questo capitolo: Curti Gabriella (2021). Sul linguaggio grafico di sintesi: segni e simboli nel mondo reale e virtuale/lnnovation in language: signs and symbols in the real world and virtual reality. In Arena A., Arena M., Mediati D., Raffa P. (a cura di). Connettere. Un disegno per annodare e tessere. Linguaggi Distanze Tecnologie. Atti del $42^{\circ}$ Convegno Internazionale dei Docenti delle Discipline della Rappresentazione/Connecting. Drawing for weaving relationship. Languages Distances Technologies. Proceedings of the $42^{\text {th }}$ International Conference of Representation Disciplines Teachers. Milano: FrancoAngeli, pp. 646-661. 


\title{
Innovation in Language: Signs and Symbols in the Real World and Virtual Reality
}

\author{
Gabriella Curti
}

Abstract

A symbols system is generally used everywhere and in every different situation. Images express everything with synthetic traditional or innovative language with many signs and symbols which refer to different meanings. In spite of many stereotypical images, graphical signs and symbols can be innovative and show highly creative patterns.

Using signs and symbols instead of words is like a visual shorthand, and today people understand more than they used to.

Moreover, signs and symbols function in giving useful information and instructions in various contexts, and all of them carry meanings. As a result, it is really important to make their meaning clear so that people do not misunderstand them, and they can be used in different applications and international contexts.

Obviously, it is possible to see lots of different examples of the same items, not only in real world, also in virtual reality, especially by surfing the Internet or using digital devices such as smartphone or iPhone, tablet or iPad, and so on. Sharing the community in social networks, for instance, signs and symbols are crucial for getting information, and for communicating too. And what about designing? Graphic designers are currently creating more interesting examples with such a slightly differences between symbols.

Keywords

visual communication, graphic design, sign, symbol, pictogram.
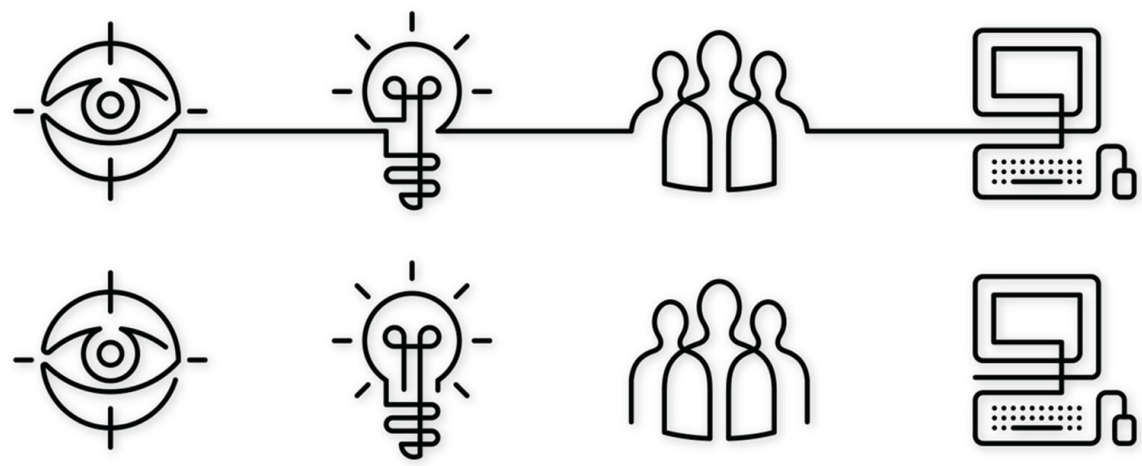


\section{Signs and symbols for effective messages}

Peirce's Theory of Signs (called 'semiotics') is based on the representing relation, i.e.: the object represented by the representamen and by the interpretant. As an object is signified by a sign to a mind, and having analyzed all the possible signs, he discussed how to classify them $[\mathrm{I}]$.

As a universal language, signs say meanings so that they are effective to go beyond barriers, especially language barriers obviously. We were used to see pictographs everywhere, in many different places in the world.

Pictographs [2] as icons are understandable and are really effective to communicate without using words. Designing pictographs, pictures should be clear and easily identifiable and the quantity that each picture represents must be given in a key to the chart.

At the moment we are getting used to see them also in the virtual reality, on the Internet for instance. Furthermore, using tablet or iPad, iPhone or smartphone surfing the Internet, people can find many unknown symbols which refer to connection. However, many different symbols have the same meaning. Concerning this, Rudolf Arnheim had already let us know that symbols are indiscriminately used everywhere [3].

Everyone can remember the five Olympic rings -perhaps the most important symbol for Olympic Games- set on the white background of the Olympic flag. It represents the contact of the athletes who had to travel throughout the world. Referring to the five continents union, Pierre de Coubertin, who was the founder of the modern Olympic Games and created it, in 1913 presented the interlaced five rings. They all were also the symbolic representation of the earth, and particularly of the different landmasses represented through five circles in different colours. As circles were also referring to the contacts, at the moment, people can see one of the 17 Sustainable Developments Goals (created for Agenda 2030 by United Nations) in which five rings mean the partnership between nations (fig. I). This result is far from surprising especially thinking what Arnheim wrote about circles: "a mere circle or dot may suffice to depict a city, a human figure, a planet; in fact, it may serve a given function much better than a more detailed likeness. [...] Being the most unspecific, universal shape, spheres, disks, and rings figure prominently in early models of the earth and the universe, not so much on the basis of observation as because unknown shape or unknown spatial relations are represented in the simplest way possible" [4].

\section{Point-line-surface to create symbols}

By creating effective symbols, grammar and syntactical rules are crucial to compound points, lines and surfaces. Sometimes a very subtle difference between them is substantial. For instance, lines could be tiny or big, linear or curved, whole or broken, points could be small or big, surfaces could be full or empty, different one from another so that, due to crucial differences symbols can be more or less attractive (fig. 2).

Circles, squares, triangles have been largely utilized everywhere. Obviously, these shapes and forms led us directly to the Isotype System a 'world language without words' a sym-

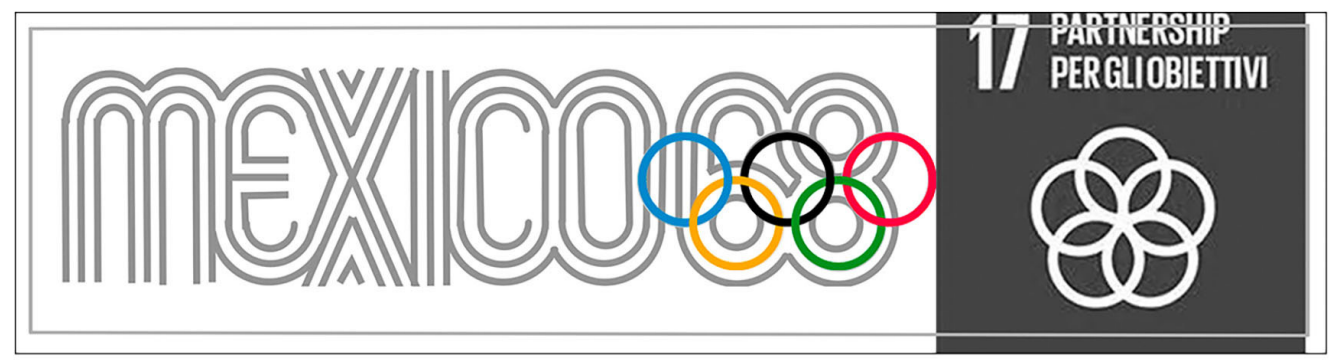


bol-based language better known as 'an alternative to written language'. As images are attractive, the Isotype System has a special value for all sort of instruction or indication and communication [5].
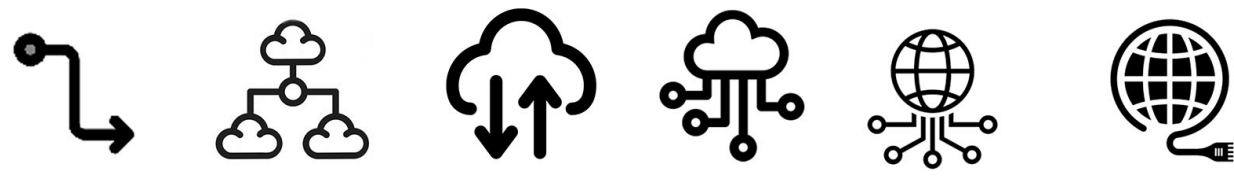

\section{Standard shapes and forms for symbols}

Regarding their use in places such as airport, railways stations and city squares, symbols shapes and forms are more effective than ever because they catch user's attention, enabling them to orientate themselves.

Circular shape is more frequently used -as everyone can remember circular road signalsto communicate information or how to use various instruments (fig. 3). They also give indications for permitted or prohibited actions, but what happens in the digital world?

Obviously, we have to keep up with new technology in our job, coming up with technological devices, as day-after-day a lot of symbols are regularly created, and also between the same members of the world's technological and advanced society. Putting information online for the global world market, symbols can help people who regularly use social media, emails, newsletters, blogs, advertisement. People use words and symbols to communicate as well - don't remember emoji for instance? What about cloud platforms, audio conferencing, and webinars across room system? As the World Wide Web is unstable and temporary, symbols will simply be lost quickly. It is possible to think that many of them are disappearing faster than anyone can plug them.

If the majority are better known, many others are completely unknown (figs. 4, 5). There are many symbols in which recognizable geometric shapes show us connections from two to six people. Due to extreme graphic synthesis, it seems that these symbols really work, either

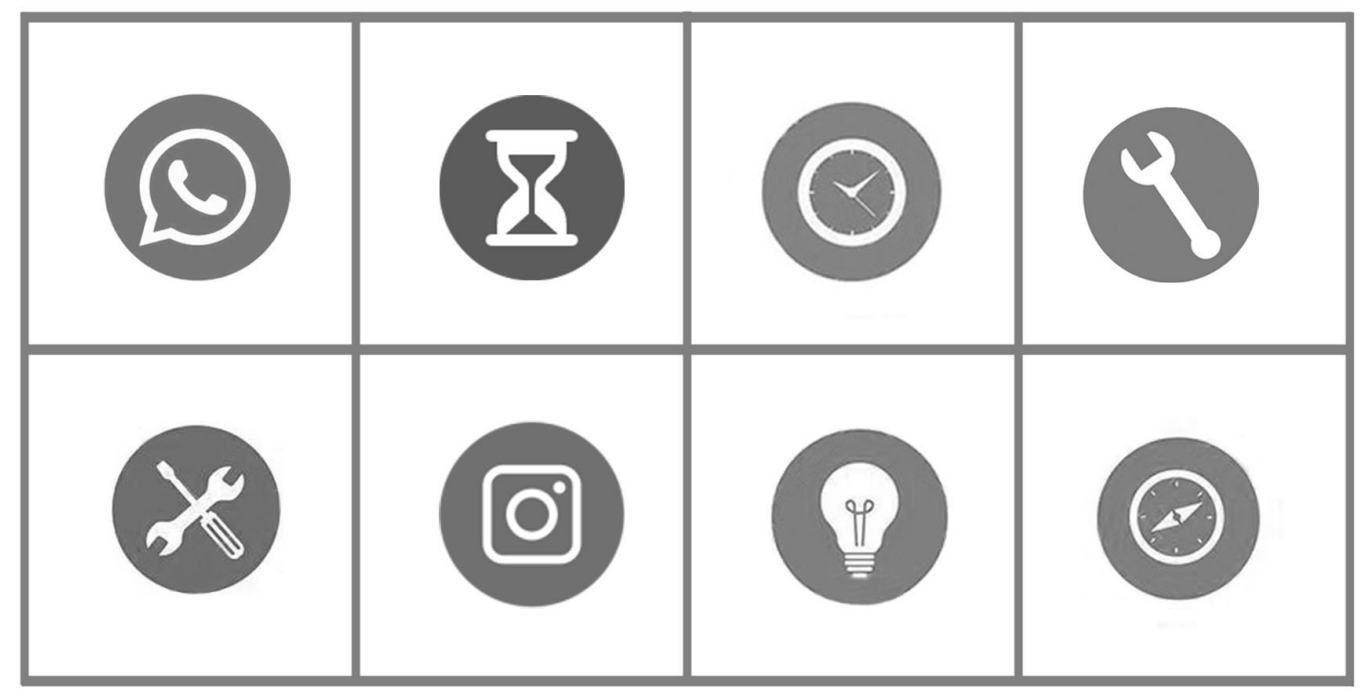


in accurate proportions or in apparently extravagant forms, and the amounts of colours emphasize their figurative value (fig. 6).

Obviously, the change of the world onto two-dimensional surfaces requires a very deep grasping of the unspoken code and symbols. As a result, circular or rectangular shapes are strictly related to the technological devices, in which they will be inserted. Nowadays, we have more powerful tools, so we can also visualize 3D symbols, but these symbols are usually created thinking about shapes and forms, matching it with different colours. There are many symbols (called cool-symbols) but they are also the same: stars -currency - bracket - card - arrows - punctuation - technical - popular - heart and smile faces. Circular shape is the most effective form, used for Apps over tablet and mobile phone touch screen. In the internet, the main symbols are really common: Bluetooth - ethernet - location - power - recycle - refresh - volume - WiFi - USB port, etc. If the electronic way and some level of technical skills are helpful for creating and managing an online interaction, regarding shopping sites users photograph items to promote them - to make safely purchases. They use social media, emails, newsletters, blogs, advertisement, putting information online for the global world market.

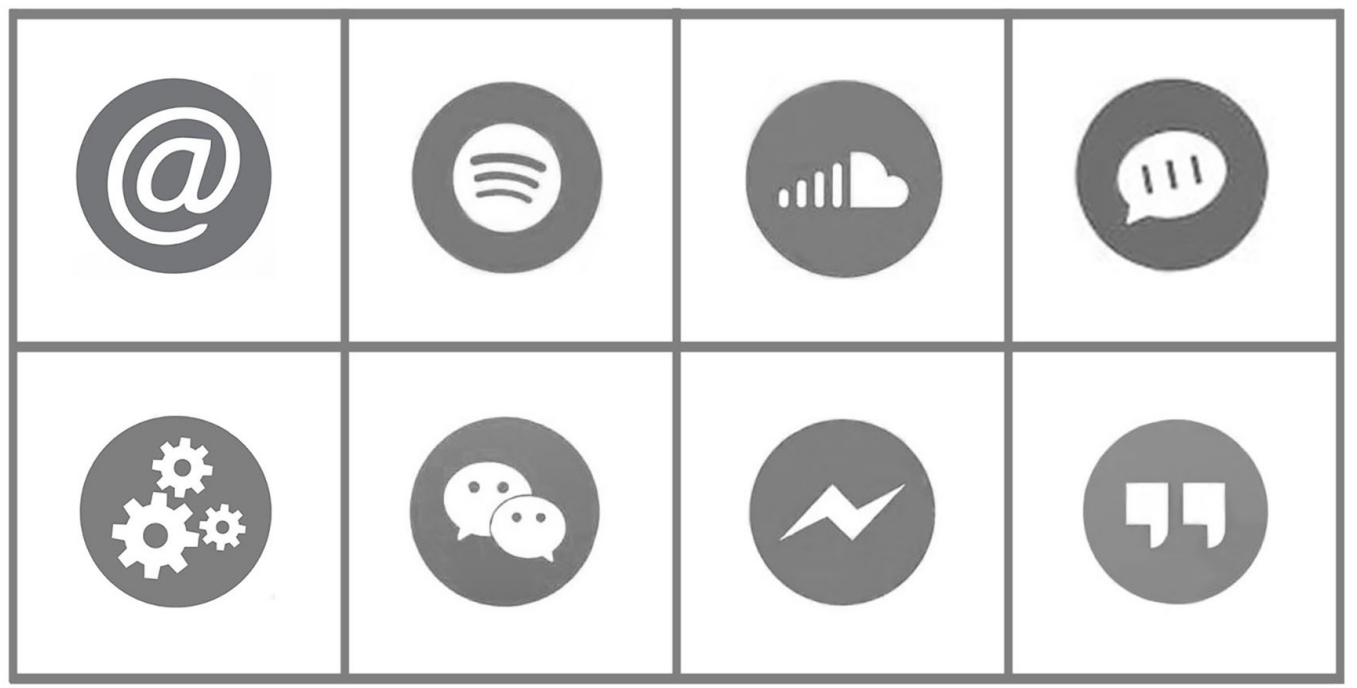

\section{How to create symbols?}

Initially, to create symbols designers think about an idea, scribbling a sheet all over or sketching daubs, and then they try to draw an image or parts of an image. Actually, everything they make is completely unknown.

Drawing by horizontal, vertical, diagonal lines to set the geometrical structure they probably realize that a geometrical grid is essential to start with symbol's creation, but the project could take a very long time and many variations during the whole process, in which both options are acceptable.

Sometimes symbols show thick or thin white lines on highlighted surface (fig. 7), on the contrary others are made by various shape and forms - either two dimensional or three dimensional. 


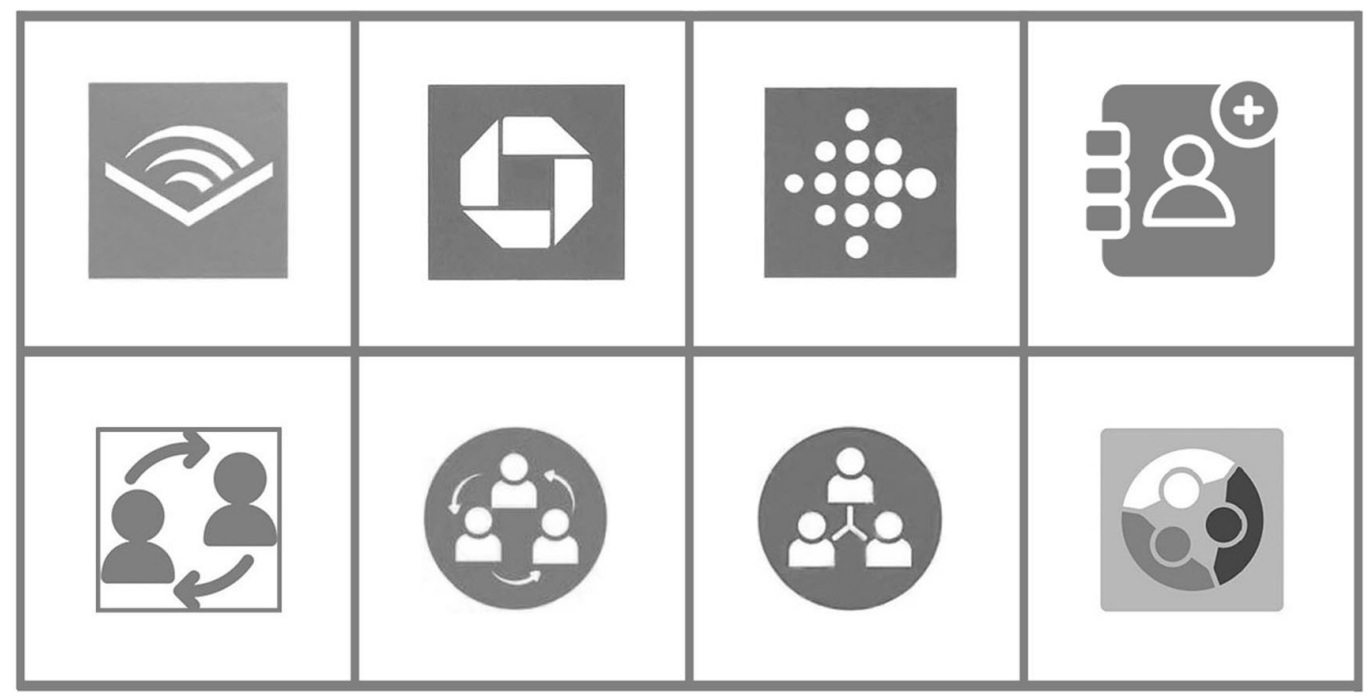

Fig. 6. Internet

from three to six people.

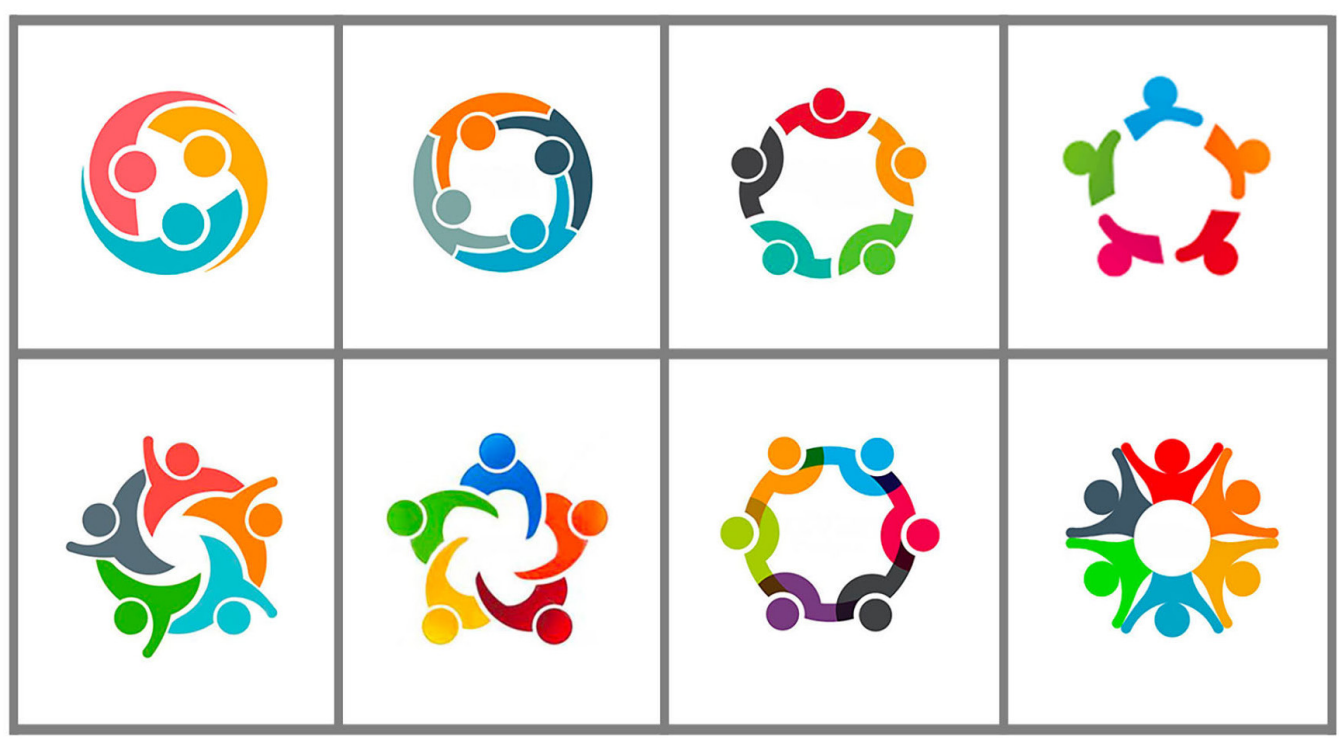



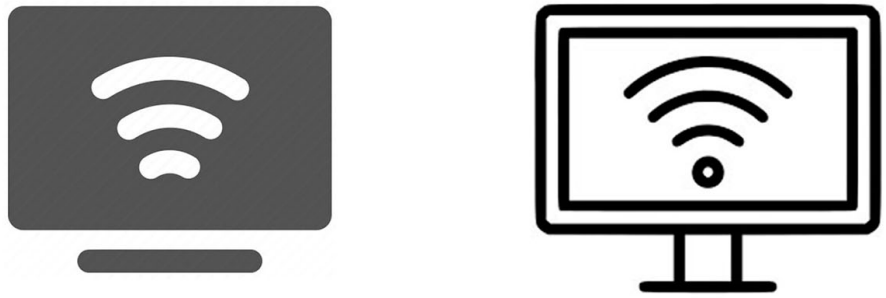

A grid is instrumental in designing symbols and it is a hidden guidance system for all of the best examples, so that, basically, using a geometric grid designers set shape, form and size in fair proportion (figs. 8,9). As a result, transmissibility and comprehensibility can be really effective. It is well known that Arnheim had already told us something about the hidden structure of a square and referring to a black disk placed on a white square he wrote: "Wherever the disk is located, it will be affected by the forces of all the hidden structural

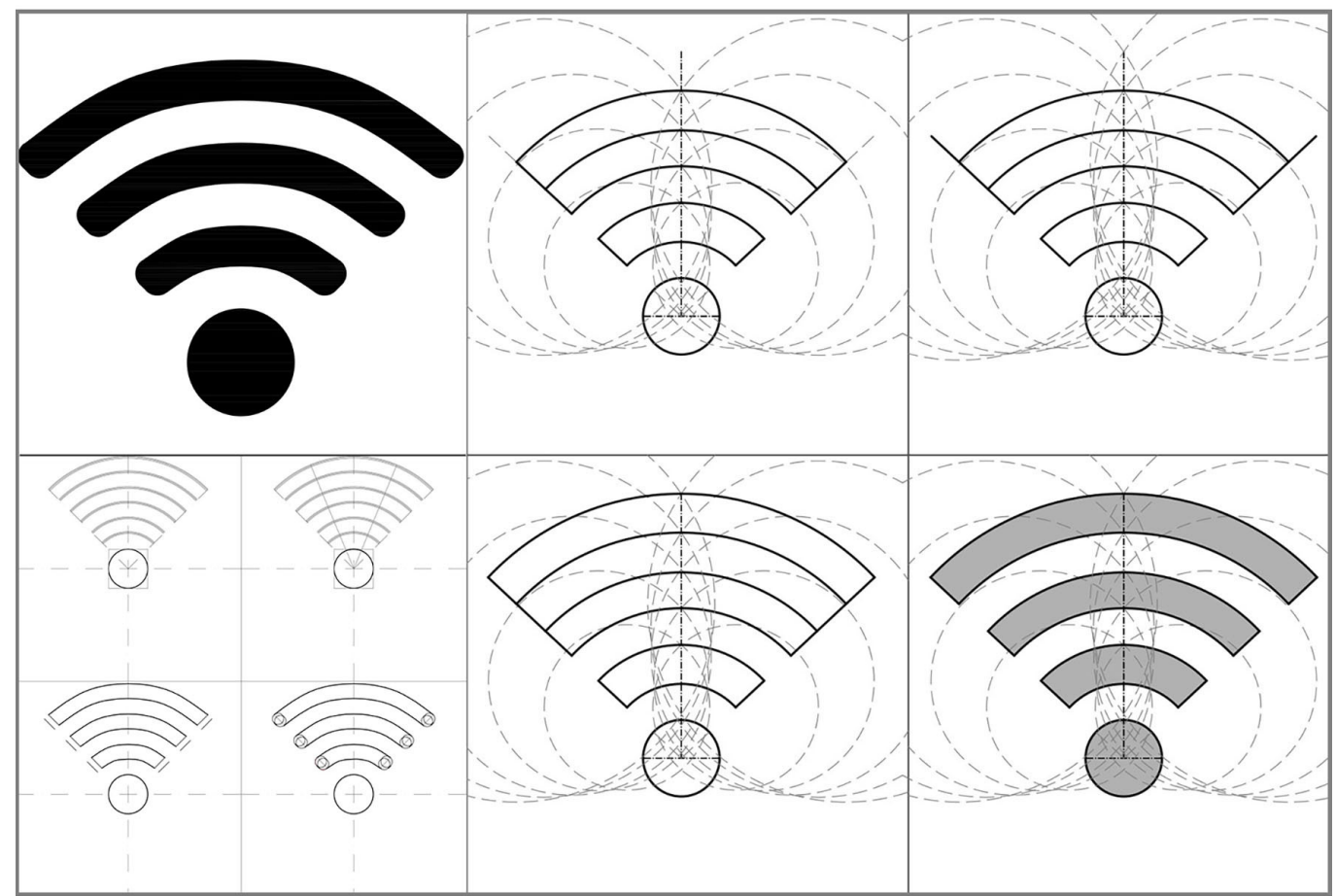

factors. The relative strength and distance of these factors will determine their effect in the total configuration. [...] In general, any location that coincides with a feature of the structural skeleton introduces an element of stability, which of course may be counteracted by other factors. [...] In ambiguous situations the visual pattern ceases to determine what is seen, and subjective factors in the observer, such as his focus of attention or his preference for a particular direction, come into play. Unless an artist welcomes ambiguities of this sort, they will induce him to search for more stable arrangements" [6]. 
Fig. 9. Hypothetical geometrical structure for People Connections Symbols.

Fig. 10. Moebius Loop. The 'recycling loop' is a consummate representation of recycling.

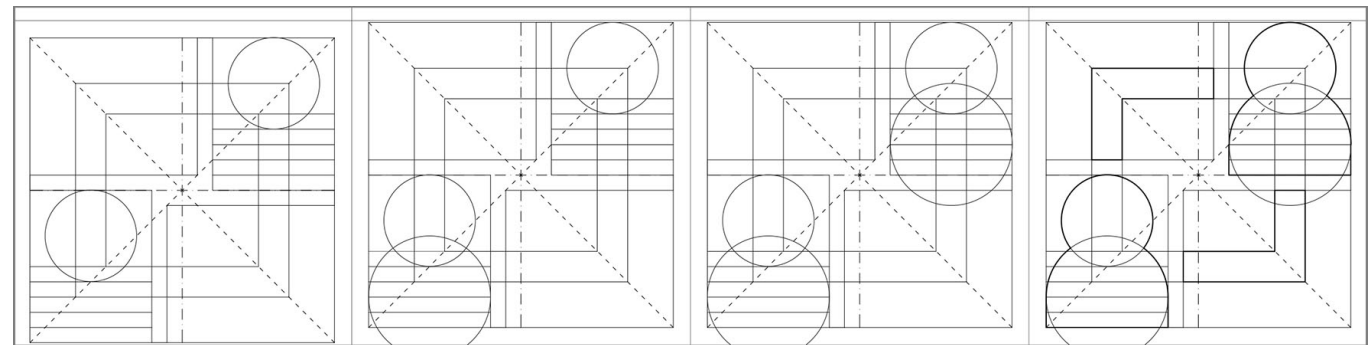

Looking carefully at the Recycle Symbols we can also find a hidden geometrical pattern. The first one (fig. 10) represents a 'Moebius loop' consisting of three-chasing-arrows in the shape of a triangle having round vertices. This 'recycling loop' is a consummate representation of recycling.

Often confused with the Moebius Loop's, the Green Dot (displayed everywhere) shows that the producer has financially contributed to the recovery and recycling of packaging. The biohazard symbols (used for viruses, toxins, spores and fungi, pathogenic micro-organism and bio-active substances) function to convey information about infectious agents presenting a risk or potential risk to the well-being of man or that pose a threat to the health of living organisms (fig. I I).

Despite their simplicity, these symbols are definitely challenging, as they are not a language of and by themselves; rather they are devices by which difficult, dangerous, or inconvenient to articulate in common language ideas are transmitted between people who have acculturated in common ways.

In visual communication symbols are getting better, and maybe the quality of the creation or designing are set to improve further. By 2030, graphic designers will have created sounds and dynamic elements to make them interactive.
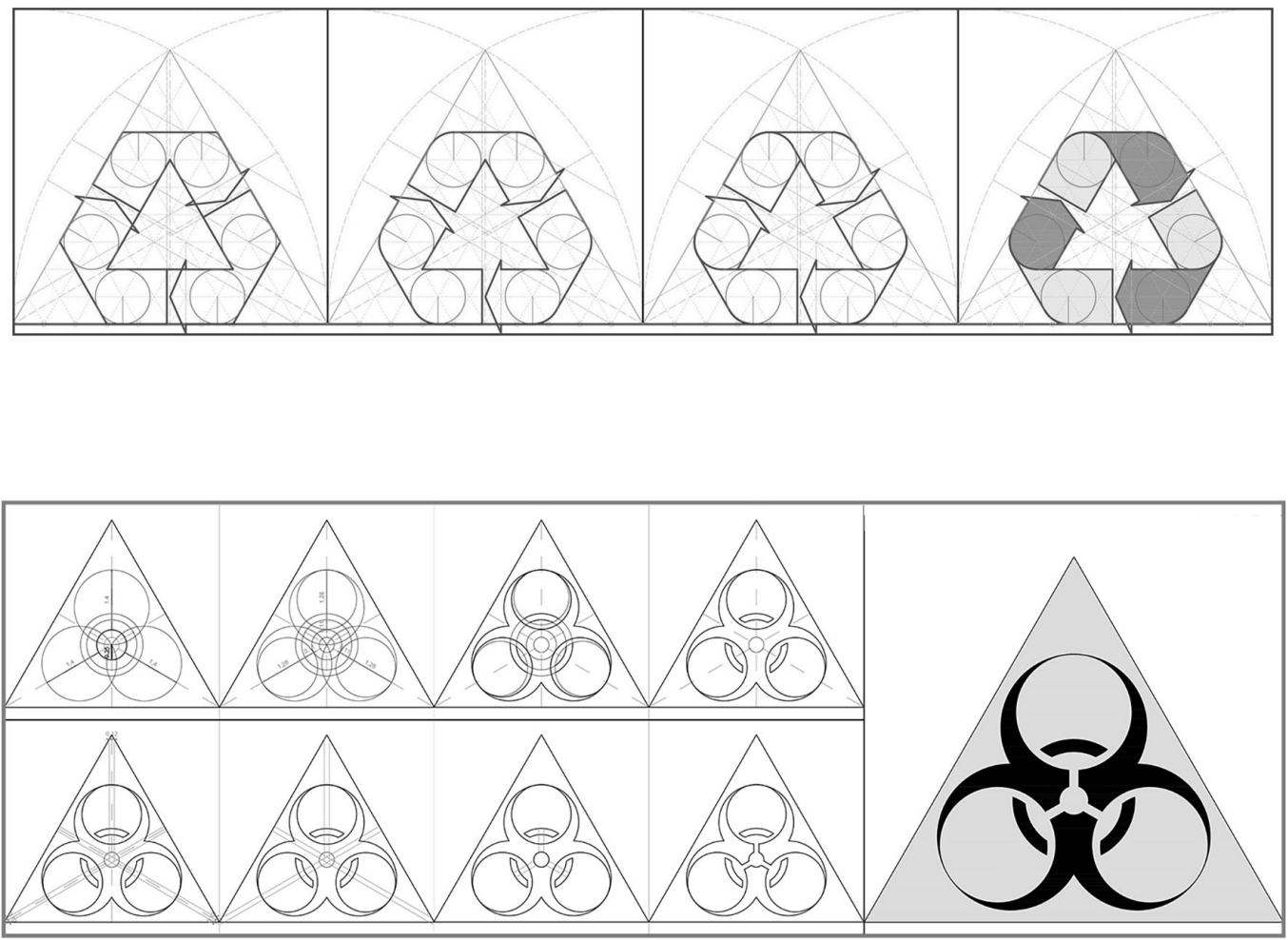

Fig. II. Biohazard Symbol. Proportioning of a size is consistent with the size of the affixing equipment or material. 


\section{Notes}

[I] Being one of the most complex semiotic theories, Peirce's theory of signs is well known by Semiotics scholars. It's also really interesting what Adrian Frutiger wrote: "It appears from archaeological evidence that human-kind has an innate feeling for geometry." See: Frutiger 1989, p. 43.

[2] Referring to picture writing, 'pictograph' or 'pictogram' (British English) are both used with the same meaning.

[3] Arnheim wrote: "The term 'symbol' is used so indiscriminately nowadays that it can be applied whenever one thing stands for another." Arnheim 1974, IV Growth, p. 164.

[4] Arnheim 1974, IV Growth, page 168.

[5] Isotype (International System of Typographic Picture Education) was developed between 1925 and 1934 by Otto Neurath and Gerd Arntz.

[6] Arnheim 1974, I Balance, pp. 10- 14.

\section{References}

Arnheim R. (2020). Arte e percezione visiva. Milano: Feltrinelli [Prima ed. Art and Visual Perception. A Psychology of the Creative Eye. Los Angeles, 1974].

Aymerich M. (2008). Simboli, pittogrammi \& silhouette. Modena: Logos. [Prima ed. Symbols, pictograms \& silhouettes. Barcelona 2008].

Fioravanti G. (2002). Il nuovo manuale del grafico. Bologna: Zanichelli.

Frutiger A. (1989). Signs and Symbols: their design and meaning. New York:Van Nostrand Reinhold.

Gallagher M., Savard L. (2006). 1000 simboli e pittogrammi: comunicazione visiva per tutte le lingue. Modena: Logos. [Prima ed. 1000 lcons, Symbols + Pictograms. Beverly MA, 2006].

Leveni P. (20 I3). In forma di parola: pittogrammi, ideogrammi, alfabeti, scritture dalla preistoria all'età moderna. Milano: BookTime.

Polano S., Vetta P. (2002). Abecedario la grafica del novecento. Milano: Mondadori Electa.

Spera M. (200 I). La progettazione grafica tra creatività e scienza. Roma: Gangemi editore.

\section{Author}

Gabriella Curti, Università degli Studi Mediterranea di Reggio Calabria, gabriella.curti@unirc.it

To cite this chapter. Curti Gabriella (2021). Sul linguaggio grafico di sintesi: segni e simboli nel mondo reale e virtuale/lnnovation in language: signs and symbols in the real world and virtual reality. In Arena A., Arena M., Mediati D., Raffa P. (a cura di). Connettere. Un disegno per annodare e tessere. Linguaggi Distanze Tecnologie. Atti del $42^{\circ}$ Convegno Internazionale dei Docenti delle Discipline della Rappresentazione/Connecting. Drawing for weaving relationship. Languages Distances Technologies. Proceedings of the $42^{\text {th }}$ International Conference of Representation Disciplines Teachers. Milano: FrancoAngeli, pp. 646-661. 